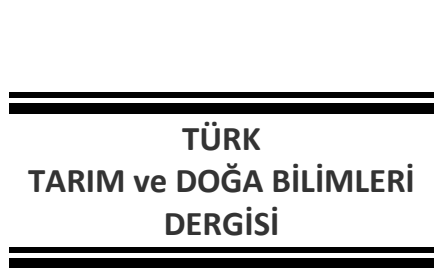

https://doi.org/10.30910/turkjans. 633544

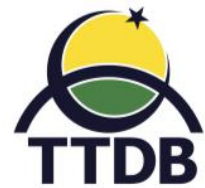

www.dergipark.gov.tr/turkjans

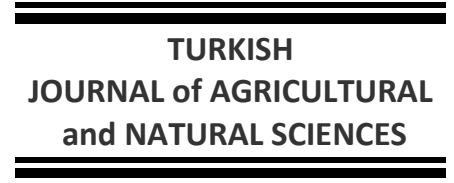

Research Article

Effects on Growth Performance of Some Chick Quality Measurements in Broilers

\author{
Turgay ŞENGÜL ${ }^{1 *}$, Mustafa ERÜKÇÜ² \\ ${ }^{1}$ Bingöl University, Faculty of Agriculture, Department of Animal Science-Bingöl \\ ${ }^{2}$ Bingöl University, Graduate School of National and Applied Sciences-Bingöl \\ *Corresponding author: tsengul2001@yahoo.com
}

Received: 25.04 .2019

Received in Revised: 20.05.2019

Accepted: 31.07.2019

\begin{abstract}
This study was conducted to examine the effect of 4 different quality criteria (chick weight, toe length, shank length and chick length) on live weight, feed consumption, feed conversion ratio and mortality in broiler chicks at the end of the fattening period. A total of 192 male broiler chicks were used in the experiment, and two separate groups were formed for each quality criterion. In 1 day-old chicks, a heavy group and a light group ( $\geq 47.7 \mathrm{~g}$ and $<47.7 \mathrm{~g}$ ) were created for chick weight; and a tall group and a short group were created for each of the toe length $(\geq 2.01 \mathrm{~cm}$ and $<2.01 \mathrm{~cm})$, shank length $(\geq 2.9 \mathrm{~cm}$ and $<2.9 \mathrm{~cm})$ and chick length $(\geq 18.3 \mathrm{~cm}$ and $<18.3 \mathrm{~cm}$ ) criteria. At the end of the six-week fattening period, the live weight was significantly higher in the heavy group compared to the light group; in the short toe group compared to the tall toe group; and in the short chick length group compared to the tall chick length group $(\mathrm{P}<0.01$ and $\mathrm{P}<0.01)$. In terms of feed consumption, more feed was consumed in the heavy group compared to the light group; in the short shank group compared to the tall shank group; and in the short chick length group compared to the tall chick length group $(P<0.01)$. The feed conversion ratios were influenced by the quality criteria, and the feed efficiency was better in the heavy group compared to the light group; in the short toe group compared to the tall toe group; and in the short chick length group compared to the tall chick length group. The mortality of the experimental groups showed significant differences in the groups other than the shank length group $(P<0.05)$.
\end{abstract}

Key words: Broiler, chick quality, growth performance, mortality.

\title{
Etlik Piliçlerde Bazı Civciv Kalite Ölçütlerinin Besi Performansı Üzerine Etkileri
}

\begin{abstract}
Özet
Bu çalışma, etlik piliç civcivlerinde 4 farklı kalite ölçütünün (civciv ağırlığı, parmak uzunluğu, incik uzunluğu ve boy uzunluğu) besi dönemi sonundaki canlı ağırlık, yem tüketimi, yemden yararlanma ve ölüm oranı üzerine etkisini incelemek amacıyla yürütülmüştür. Denemede toplam 192 adet erkek etlik piliç civcivi kullanılmış olup, her bir kalite ölçütü için iki farklı grup oluşturulmuştur. Günlük civcivlerde vücut ağırlığı için ağır ve hafif $(\geq 47.7$ ve $<47.7 \mathrm{~g}$ ); parmak uzunluğu ( $\geq 2.01$ ve $<2.01 \mathrm{~cm}$ ), incik uzunluğu $(\geq 2.9$ ve $<2.9$ ) ve boy uzunluğu için uzun ve kısa ( $\geq 18.3$ ve $<18.3$ ) olmak üzere ikişer grup oluşturulmuştur. Altı haftalık besi dönemi sonunda; ağır vücut grubu hafif gruba, kısa parmak grubu uzun parmak grubuna, kısa boy grubu uzun boy grubuna göre önemli $(P<0.01$ ve $P<0.01)$ düzeyde yüksek canlı ağırlığa sahip olmuşlardır. Yem tüketimi bakımından ağır vücut grubu hafif gruba, kısa incik uzunluğu grubu uzun gruba ve kısa boy grubu ise uzun boy grubuna oranla daha fazla $(P<0.01)$ yem tüketmiştir. Yemden yararlanma düzeyleri, kalite ölçütlerinden etkilenmiş olup ağır vücut grubu hafif gruba, kısa parmak grubu uzun parmak grubuna ve kısa boy grubu uzun boy grubuna oranla daha iyi yemden yararlanmıştır. Deneme gruplarına ait ölüm oranları ise, incik uzunluğu grubu dışındaki gruplarda önemli $(P<0.05)$ düzeyde farklılıklar göstermiştir.
\end{abstract}

Anahtar kelimeler: Broiler, civciv kalitesi, besi performansı, ölüm oranı. 


\section{Introduction}

One of the factors affecting profitability in broiler chick production is the quality of chicks. Chick quality is an indicator of success of hatcheries and a prerequisite for the productivity of broiler production (İpek and Sözcü, 2013). Tona et al. (2005) have reported that one of the important factors that have a positive or negative impact on the performance of broiler chicks reaching the slaughter age is the quality of chicks. For this reason, it has been explained that chick quality parameters should be utilized in determining the quality of chicks. In a production that begins with low quality chicks, yield losses can reach a level that cannot be compensated. Chick quality is of great importance in maximizing the return on investment in every step of the poultry production chain (Şeremet, 2012).

There are several factors that are effective on the quality of chicks, and chicks with different qualities are achieved depending on the effects of these factors. Factors such as the age of breeding flock, storage conditions of incubation eggs, breed and incubation efficiency affect the quality of chicks and therefore the growth rate of broiler chicks (Kamanlı and Durmuş, 2010). Hill (2002) has reported that the weight at the time of hatching and the duration of the incubation period in poultry are important criteria used in measuring and determining the incubation quality. Wilson et al. (1984) have reported that in subsequent periods, weight differences increase between 1 day-old chicks of turkeys and broilers with different weights, and that the weight at the time of hatching affects the feed conversion ratio. Similarly, Hill (2001) has also reported that chicks with live weight above the average at the time of hatching more live weight gain in subsequent periods.

Ould-Ali and Schulte-Drüggelte (2016) have reported that essential quality parameters such as chick weight and chick length are qualitative characteristics. The same researchers have explained that there is a high correlation between chick weight and egg weight, and that chick length significantly affects the performance of development at the end of the fattening period. A number of studies have shown that chick length correlates with chick performance. Reijrink and Molenaar (2006) have reported that there is a positive correlation between live weight and chick length in broiler chicks on the $7^{\text {th }}$ day. They have reported that internal organs of chicks with a tall chick length at hatching are better developed than those of shorter chicks. Molenaar et al. (2007) have found that a $1 \mathrm{~cm}$ difference in the length of 1 dayold chicks leads to an average of $264 \mathrm{~g}$ live weight and $45 \mathrm{~g}$ breast meat increase when they reach 38 days old. Ketels (2011) has reported that chick length correlates not only with the broiler performance but also with the development of internal organs. He has stated that heart and liver weights have significant differences in chicks with tall and short chick lengths. Moreover, he has said that it is possible to calculate the flock uniformity by measuring the chick length of 1 day-old chicks. Kamanlı and Durmuş (2014) have reported that measuring chick length is the fastest method in determining the quality of chicks.

Meijerhof (2005) has reported that most of the time, the weight of 1 day-old chicks in broiler chicks is considered to be an important indicator of the quality of chicks, and it is both easy and objective to measure the weight of chicks. On the other hand, it has been emphasized that it is more practical to measure chick length or shank length when determining the quality of chicks. Moreover, he has also explained that the chick length in 1 dayold chicks has a stronger relationship with the broiler performance in the $6^{\text {th }}$ week compared to the relationship between chick length and weight on day 1. Molenaar et al. (2008) have reported that weight and chick length at hatching are important criteria in determining the quality of broiler chicks, but the relationships between these parameters and the performance in subsequent periods are not well known. In their study, they have found that there is a positive and significant correlation between the chick length at hatching and slaughter weight in male broiler chicks, but there is no significant relationship between the weight at hatching and the weight at the time of slaughter. There was no significant correlation between the chick length at hatching and feed efficiency in male broilers. Researchers have reported that chick length is an important and suitable parameter in determining the performance of chicks. Ojedapo (2013) have estimated the repeatability for chick weight, chick length and shank length in 2, 4 and 6 week-old broiler chicks as $0.33,0.03,0.45 ; 0.63$, $0.81,0.74$; and $0.69,0.38,0.14$, respectively.

In this study, it was aimed to determine the effects of certain quality criteria such as chick weight, shank length, toe length and chick length on the growth performance and mortality during the fattening period in broiler chickens.

\section{Material and Methods}

This experiment was carried out for 42 days in a windowed poultry house belonging to the Department of Animal Science, Faculty of Agriculture, Bingöl University. A total of 192 Ross 308 male chicks were used in the study. The chicks were housed in multi-storey broiler cages during the first 2 weeks and then taken to a floor system 
with a base. The broiler chicks were fed with feed containing $24 \%$ crude protein and $3000 \mathrm{kcal} / \mathrm{kg} \mathrm{ME}$ on day 1-14 and with feed containing $22 \%$ crude protein and $3200 \mathrm{kcal} / \mathrm{kg}$ ME from day 15 until the day of slaughter. Feed and water needs of the animals were met as ad libitum throughout the breeding period. A lighting program was applicated in the form of 24 hours uninterrupted light for the first 3 days and 23 hours of light- 1 hour of darkness after day 3. Live weight and feed consumption were measured weekly, and deaths were recorded daily. Live weight, feed consumption, feed conversion ratio and mortality of the groups were measured in the study.

The chicks were labeled with a wing number, they were weighed, and their live weights were recorded on the first day. The chicks were then divided into 4 different groups (with 48 chicks in each group) according to 4 separate quality criteria (chick weight, chick length, shank length, and toe length).

In order to create the chick weight groups, 48 randomly selected chicks were divided into two groups (24 heavy-24 light) according to their weights. The 24 chicks that were in the heavy group were randomly assigned into 3 groups, and thus, 3 replicate groups with 8 chicks were created. The same method was carried out for the light group, and 3 replicate light groups were formed. To determine chick lengths, the 48 chicks were stretched each, and the distance between the beak and the beginning of nail in the middle toe of right foot was measured. The chicks, whose chick lengths were measured, were assigned into 2 groups with 3 replications in the same way as the chick weight groups were formed, but this time they were assigned into the tall chick length and short chick length groups. In order to form the shank length groups, the distance between the elbow of the right leg and the starting point of the ankle was measured for each of the 48 chicks by the help of an electronic caliper, and the tall and short groups were formed. In order to create the toe-length groups, the distance between the beginning of the middle toe of the right foot and the starting point of the nail was measured for each of the 48 chicks again by the help of an electronic caliper, and the tall and short groups were formed.

Data of the examined features were analyzed in the SPSS 22.0 statistical package program. Analyses of variance and t-tests were carried out to determine differences between the groups. The Duncan test was used to determine the degree of significance of differences between the average values.

\section{Results and Discussion Live weight}

The live weight averages of broiler chicks belonging to the experimental groups formed according to different quality criteria are shown in Table 1.

Table 1. Live weight averages (g) and standard errors of the broiler chicks in the experimental groups

\begin{tabular}{|c|c|c|c|c|c|c|}
\hline \multirow{2}{*}{ Weeks } & \multicolumn{2}{|c|}{ Chick weight (g) } & \multirow{2}{*}{$\mathbf{P}$} & \multicolumn{2}{|c|}{ Toe length $(\mathrm{cm})$} & \multirow{2}{*}{$\mathbf{P}$} \\
\hline & Heavy $\geq 47.7$ & Light $<47.7$ & & Tall $\geq 2.01$ & Short $<2.01$ & \\
\hline 0 & $50.5 \pm 0.1 \mathrm{a}$ & $44.5 \pm 0.1 b$ & $*$ & $48.5 \pm 0.1 a$ & $46.5 \pm 0.1 b$ & $*$ \\
\hline 1 & $153.5 \pm 3.6 a$ & $147.5 \pm 3.3 a$ & NS & $145.5 \pm 3.6 b$ & $159.5 \pm 4.2 \mathrm{a}$ & $*$ \\
\hline 2 & $364.7 \pm 9.0 a$ & $345.5 \pm 9.3 a$ & NS & $342.5 \pm 8.9 a$ & $361.5 \pm 8.1 a$ & NS \\
\hline 3 & $641.5 \pm 19.2 \mathrm{a}$ & $619.0 \pm 17.9 b$ & $*$ & $612.5 \pm 19.0 a$ & $658.5 \pm 15.7 b$ & $*$ \\
\hline 4 & $1073.5 \pm 35.0 a$ & $1019.5 \pm 37.5 b$ & $*$ & $1023.5 \pm 33.2 b$ & $1097.5 \pm 27.4 a$ & $*$ \\
\hline 5 & $1680.5 \pm 50.2 \mathrm{a}$ & $1558.0 \pm 71.4 b$ & $*$ & $1563.0 \pm 42.5 b$ & $1709.5 \pm 38.9 a$ & $* *$ \\
\hline 6 & $2269.0 \pm 64.1 \mathrm{a}$ & $2063.5 \pm 97.1 b$ & $* *$ & $2177.5 \pm 43.7 a$ & $2305.0 \pm 53.4 b$ & $*$ \\
\hline \multirow{2}{*}{ Weeks } & \multicolumn{2}{|c|}{ Shank length $(\mathrm{cm})$} & & \multicolumn{2}{|c|}{ Chick length $(\mathrm{cm})$} & \\
\hline & Tall $\geq 2.9$ & Short $<2.9$ & $\mathbf{P}$ & Tall $\geq 18.3$ & Short $<18.3$ & $\mathbf{P}$ \\
\hline 0 & $46.5 \pm 0.1 a$ & $46.0 \pm 0.1 \mathrm{a}$ & NS & $47.5 \pm 0.1 \mathrm{a}$ & $46.0 \pm 0.1 b$ & $*$ \\
\hline 1 & $153.5 \pm 2.7 a$ & $152.5 \pm 3.2 \mathrm{a}$ & NS & $148.5 \pm 3.7 a$ & $150.5 \pm 3.9 a$ & NS \\
\hline 2 & $352.5 \pm 7.5 a$ & $360.5 \pm 9.2 a$ & NS & $328.5 \pm 8.2 a$ & $334.5 \pm 8.4 a$ & NS \\
\hline 3 & $582.0 \pm 15.0 a$ & $617.0 \pm 17.1 \mathrm{a}$ & NS & $533.5 \pm 14.6 a$ & $548.5 \pm 19.0 a$ & NS \\
\hline 4 & $1012.5 \pm 28.7 a$ & $1044.0 \pm 32.1 a$ & NS & $921.5 \pm 33.7 a$ & $959.5 \pm 29.2 a$ & NS \\
\hline 5 & $1593.5 \pm 40.8 b$ & $1634.5 \pm 46.5 a$ & $*$ & $1441.5 \pm 50.6 a$ & $1482.5 \pm 0.2 \mathrm{a}$ & NS \\
\hline 6 & $2224.5 \pm 52.0 a$ & $2290.5 \pm 61.3 a$ & NS & $1945.5 \pm 66.6 a$ & $2113.5 \pm 46.4 b$ & $*$ \\
\hline
\end{tabular}

a, b: Differences between means in the same row with different letters are significant. *: $P<0.05, * *$ : $P<0.01, N S$ : Non-significant.

The live weight averages of the groups were found to be 2269.0, 2063.5, 2177.5, 2305.0, 2224.5, 2290.5, 1945.5 and $2113.5 \mathrm{~g}$, for the heavy group, light group, tall toe group, short toe group, tall shank group, short shank group, tall chick length group and short chick length group, respectively. 
The differences between the averages were significant for the chick weight, toe length and chick length groups $(P<0.05$ and $P<0.01)$ and were found to be insignificant for the shank length group. Petek et al. (2008) have found a significant correlation between chick length and live weight in broiler chicks at hatching. They have reported that chick length instead of live weight can be used to determine the potential of growth in 1 day-old chicks. They have also explained that there is a significant correlation between chick length and live weight in 1 day-old chicks.

The differences between the live weights of 6 week-old chicks, which were assigned into two weight groups ( $\geq 47.7$ and $<47.7 \mathrm{~g}$ ) when they were 1 day old, were found to be significant $(P<0.01)$. At the end of the $6^{\text {th }}$ week, the heavy group reached a greater live weight compared to the light group. The chicks' being heavy or light on the first day significantly affected their live weights in the $6^{\text {th }}$ week $(P<0.01)$.

The differences between the live weights of 6 week-old chicks, which were assigned into two different toe length groups ( $\geq 2.01$ and $<2.01 \mathrm{~cm}$ ) when they were 1 day old, were found to be significant $(P<0.01)$. At the end of the sixth week, the group with short toes had a greater live weight than the group with tall toes. The chicks' having tall or short toes on the first day significantly affected their live weights in the $6^{\text {th }}$ week $(P<0.05)$.

The differences between the live weights of 6 week-old chicks, which were assigned into two different shank length groups ( $\geq 2.9$ and $<2.9 \mathrm{~cm}$ ) when they were 1 day old, were found to be insignificant. The chicks' having tall or short shanks on the first day did not significantly affect their live weights in the $6^{\text {th }}$ week. Yahaya et al. (2012) has reported that there are significant correlations between chick weight and shank length in broiler chicks belonging to 2 different genotypes.

The differences between the live weights of 6 week-old chicks, which were assigned into two different chick length groups ( $\geq 18.3$ and $<18.3 \mathrm{~cm}$ ) when they were 1 day old, were found to be significant $(P<0.05)$. The chicks with short chick length reached a greater live weight than those with tall chick length. The chicks' having tall or short chick lengths at hatching significantly affected their live weights in the $6^{\text {th }}$ week. Wolanski et al. (2006) have reported that in broiler chicks, the chick length and shank length at hatching have a stronger relationship with the chick weight on day 14 than with the chick weight on day 1. Geidam et al. (2007) have reported in their study that there are statistically significant differences in weight in broiler chicks at hatching, and that there are no significant differences in chick length at hatching.

\section{Feed consumption and feed conversion ratio}

Feed consumption averages of broiler chicks with different chick criteria on day 1 are given in Table 2.

Table 2. Feed consumption averages (g) and standard errors of the broiler chicks in the experimental groups

\begin{tabular}{|c|c|c|c|c|c|}
\hline \multirow{2}{*}{ Weeks } & \multicolumn{2}{|c|}{ Chick weight (g) } & \multicolumn{2}{|c|}{ Toe length (cm) } & \multirow{2}{*}{$\mathbf{P}$} \\
\hline & Heavy $\geq 47.7$ & Light $<47.7$ & Tall $\geq 2.01$ & Short $<2.01$ & \\
\hline $0-1$ & $148.5 \pm 5.4 a$ & $148.5 \pm 1.1 a$ & $142.5 \pm 1.1 a$ & $144.5 \pm 1.4 a$ & NS \\
\hline $0-2$ & $476.5 \pm 9.4 a$ & $459.5 \pm 5.4 a$ & $449.5 \pm 5.2 \mathrm{a}$ & $478.5 \pm 7.4 a$ & NS \\
\hline $0-3$ & $899.5 \pm 18.4 a$ & $865.0 \pm 14.7 \mathrm{~b}$ & $952.5 \pm 11.9 a$ & $981.5 \pm 12.4 a$ & $*$ \\
\hline $0-4$ & $1654.5 \pm 39.7 a$ & $1595.0 \pm 29.4 b$ & $1833.5 \pm 21.3 a$ & $1759.0 \pm 19.4 b$ & $* *$ \\
\hline $0-5$ & $2801.5 \pm 22.1 a$ & $2635.5 \pm 19.4 b$ & $2876.5 \pm 17.5 a$ & $2842.0 \pm 30.6 a$ & $* *$ \\
\hline $0-6$ & $4122.5 \pm 19.2 a$ & $3930.5 \pm 24.8 b$ & $4103.0 \pm 36.7 a$ & $4164.5 \pm 22.4 a$ & $* *$ \\
\hline \multirow{2}{*}{ Weeks } & \multicolumn{2}{|c|}{ Shank length $(\mathrm{cm})$} & \multicolumn{2}{|c|}{ Chick length $(\mathrm{cm})$} & \\
\hline & Tall $\geq 2.9$ & Short $<2.9$ & Tall $\geq 18.3$ & Short $<18.3$ & $\mathbf{P}$ \\
\hline $0-1$ & $131.5 \pm 3.4 a$ & $131.0 \pm 2.8 a$ & $140.5 \pm 2.8 a$ & $132.5 \pm 2.8 a$ & NS \\
\hline $0-2$ & $434.5 \pm 8.9 a$ & $459.5 \pm 8.4 a$ & $414.0 \pm 4.9 a$ & $431.5 \pm 5.1 a$ & NS \\
\hline $0-3$ & $851.5 \pm 13.1 b$ & $941.5 \pm 12.6 a$ & $812.0 \pm 12.3 a$ & $864.5 \pm 17.2 a$ & $*$ \\
\hline $0-4$ & $1577.5 \pm 35.7 b$ & $1721.5 \pm 23.8 a$ & $1492.0 \pm 20.9 b$ & $1600.5 \pm 18.6 a$ & $* *$ \\
\hline $0-5$ & $2547.5 \pm 34.4 b$ & $2744.5 \pm 35.1 a$ & $2457.5 \pm 307 b$ & $2612.5 \pm 28.4 a$ & $* *$ \\
\hline $0-6$ & $3930.0 \pm 30.4 a$ & $4085.5 \pm 41.3 b$ & $3665.5 \pm 495 b$ & $3889.5 \pm 36.5 a$ & $* *$ \\
\hline
\end{tabular}

$\mathrm{a}, \mathrm{b}$ : Differences between means in the same row with different letters are significant. NS: Non-significant, ${ }^{*}$ : $\mathrm{P}<0.05, * *: \mathrm{P}<0.01$.

Considering the feed consumption values of the experimental groups in Table 2, the feed consumption values between 0-6 weeks were found to be $4122.5,3930.5,4103.0,4164.5,3930.0$,
4085.5, 3665.5 and 3889.5 g, for the chick weight, toe length, shank length and chick length groups, respectively. In this period, the differences between the heavy group and the light group, between the 
tall shank group and the short shank group, and between the tall chick length group and the short chick length group were found statistically significant in terms of feed consumption $(P<0.01)$. The feed consumption values in the 0-6 week period of the chicks, which were grouped on the first day according to live weights, shank lengths and chick lengths, were significantly different $(P<0.05)$.

The highest feed consumption was in the short toe group with $4164.9 \mathrm{~g}$, which was followed by the heavy group with $4122.6 \mathrm{~g}$, the tall toe group with $4103.0 \mathrm{~g}$, the short-shank group with $4085.6 \mathrm{~g}$, the light group with $3930.5 \mathrm{~g}$, the tall shank group with $3930.3 \mathrm{~g}$, the short chick length group with $3889.0 \mathrm{~g}$, and the tall chick length group with 3665.4 g. Based on the results, it was found that the feed consumption of the chicks, which had greater values in terms of chick weight, shank length and toe length on the first day, were significantly different at the end of the 6 weeks of fattening period $(P<0.05)$.

The cumulative feed conversion ratios of the broiler chicks throughout the fattening period, which had different chick criteria on day 1 , are given in Table 3. Considering Table 3, it is seen that the differences between the feed conversion ratios in the $3^{\text {rd }}, 4^{\text {th }}, 5^{\text {th }}$ and $6^{\text {th }}$ weeks were statistically significant $(P<0.05, P<0.01)$. Based on the results, the groups benefiting the most from the feed between the weeks 0 and 6 were the shank length groups with the values of 1.80 and 1.82 . At the end of the $6^{\text {th }}$ week, the feed conversion ratios according to the chick weight, toe length and chick length, which were the chick quality criteria, were affected significantly $(P<0.01)$, whereas the shank length was affected insignificantly.

Table 3. Cumulative feed conversion ratios $(\mathrm{g} / \mathrm{g}$ ) and standard errors of the broiler chicks in the experimental groups

\begin{tabular}{|c|c|c|c|c|c|}
\hline \multirow{2}{*}{ Weeks } & \multicolumn{2}{|c|}{$\begin{array}{c}\text { Chick weight (g) } \\
\end{array}$} & \multicolumn{2}{|c|}{ Toe length $(\mathrm{cm})$} & \multirow{2}{*}{$\mathbf{P}$} \\
\hline & Heavy $\geq 47.7$ & Light $<47.7$ & Tall $\geq 2.01$ & Short $<2.01$ & \\
\hline $0-1$ & $1.44 \pm 0.03 a$ & $1.45 \pm 0.03 a$ & $1.46 \pm 0.02 a$ & $1.28 \pm 0.02 a$ & NS \\
\hline $0-2$ & $1.51 \pm 0.04 a$ & $1.52 \pm 0.03 a$ & $1.53 \pm 0.04 a$ & $1.51 \pm 0.03 a$ & NS \\
\hline $0-3$ & $1.52 \pm 0.03 a$ & $1.50 \pm 0.02 \mathrm{a}$ & $1.68 \pm 0.03 a$ & $1.60 \pm 0.03 b$ & $*$ \\
\hline $0-4$ & $1.61 \pm 0.03 a$ & $1.63 \pm 0.04 a$ & $1.88 \pm 0.03 a$ & $1.67 \pm 0.03 b$ & $* *$ \\
\hline $0-5$ & $1.71 \pm 0.05 b$ & $1.74 \pm 0.03 a$ & $1.89 \pm 0.03 a$ & $1.70 \pm 0.03 b$ & $* *$ \\
\hline $0-6$ & $1.85 \pm 0.03 b$ & $1.99 \pm 0.03 a$ & $1.92 \pm 0.02 \mathrm{a}$ & $1.84 \pm 0.01 b$ & $* *$ \\
\hline \multirow{2}{*}{ Weeks } & \multicolumn{2}{|c|}{ Shank length $(\mathrm{cm})$} & \multicolumn{2}{|c|}{ Chick length $(\mathrm{cm})$} & \\
\hline & Tall $\geq 2.9$ & Short $<2.9$ & Tall $\geq 18.3$ & Short $<18.3$ & $\mathbf{P}$ \\
\hline $0-1$ & $1.23 \pm 0.03 a$ & $1.22 \pm 0.02 \mathrm{a}$ & $1.39 \pm 0.02 a$ & $1.26 \pm 0.02 a$ & NS \\
\hline $0-2$ & $1.42 \pm 0.03 a$ & $1.46 \pm 0.03 a$ & $1.47 \pm 0.03 a$ & $1.49 \pm 0.02 \mathrm{a}$ & NS \\
\hline $0-3$ & $1.57 \pm 0.04 b$ & $1.64 \pm 0.03 a$ & $1.67 \pm 0.02 b$ & $1.71 \pm 0.03 a$ & $*$ \\
\hline $0-4$ & $1.63 \pm 0.04 b$ & $1.72 \pm 0.02 a$ & $1.70 \pm 0.03 b$ & $1.75 \pm 0.04 a$ & $* *$ \\
\hline $0-5$ & $1.64 \pm 0.04 b$ & $1.72 \pm 0.03 a$ & $1.76 \pm 0.03 b$ & $1.81 \pm 0.03 a$ & $* *$ \\
\hline $0-6$ & $1.80 \pm 0.01 a$ & $1.82 \pm 0.02 a$ & $1.93 \pm 0.03 a$ & $1.88 \pm 0.02 b$ & $* *$ \\
\hline
\end{tabular}

a, b: Differences between means in the same row with different letters are significant. NS: Non-significant. *: $\mathrm{P}<0.05, * *: \mathrm{P}<0.01$.

\section{Mortality}

The weekly mortality rates of the broiler chicks, which had different chick criteria on day 1 , are given in Table 4. The differences between mortality rates in weeks $1,3,5$ and 0-6 were found to be statistically significant $(P<0.05)$ in the experimental groups. Based on the results, the weights, toe lengths and chick lengths of the chicks on day 1 significantly affected the mortality at the end of the sixth week.

In this study, one day-old broiler chicks were grouped according to certain quality criteria. The effects of the quality criteria on fattening performance and carcass quality were investigated. Statistically significant differences were found among the live weights at the end of the fattening period, in the groups except for the shank length groups $(P<0.05, P<0.01)$. Whether the length of the shank was short and tall was not effective on live weight in all weeks except for week 5 .

The selection of 1 day-old broiler chicks based on chick weights was effective on the live weight in week 6 , and the heavy group had a greater live weight. The difference in toe lengths also affected the live weights in week 6 . The short toe group had greater live weights than the tall toe group. The chick length of the chicks also significantly influenced the live weight at the end of the fattening period, and the chicks with short chick length had more live weights than the chicks with tall chick length. The greater the weight of the chicks at hatching was, the heavier the carcass and edible internal organ weights were in the subsequent periods. The results obtained from this 
study were similar to those reported by Abiola et al. (2008).

In all groups in terms of the values of the cumulative feed consumption, there were no statistically significant differences between the averages of weeks $0-1$ and 0-2. The differences between feed consumption values in weeks $0-3$ were found to be statistically significant $(P<0.05)$. Considering weeks 0-4, 0-5 and 0-6, the differences between feed consumption values were found to be significant $(P<0.01)$. Based on the results, having different live weights, shank lengths and toe lengths on day 1 were found to significantly affect the feed consumption at the end of the 6-week fattening period $(\mathrm{P}<0.05)$.

The differences between the averages of the feed conversion rates of the groups were not statistically significant for weeks $0-1$ and $0-2$, whereas they were found to be significant for weeks $0-3,0-4,0-5$ and $0-6(P<0.05, P<0.01)$. At the end of the six-week fattening period, the differences between the heavy group and the light group, between the tall shank group and the short-shank group, and between the tall chick length group and the short chick length group were found statistically significant in terms of feed consumption $(P<0.01)$. Among the chicks grouped according to live weights, shank lengths and chick lengths on day 1 , the heavy group consumed more feed compared to the light group, the short-shank group compared to the tall shank group, and the group with short chick length consumed more feed compared to the group with tall chick length in the $0-6$ week period. And the differences between them were found to be significant $(P<0.05)$. In the $0-6$ week period, the best feed utilization rate was seen in the tall shank group with 1.80 . The worst feed utilization rate was in the light group with 1.99 .

The differences between mortality rates in weeks $1,3,5$ and 0-6 were found to be statistically significant $(P<0.05, P<0.01)$ when the mortality rates of the experimental groups were examined. Based on the results, the weights, toe lengths and chick lengths of the chicks on day 1 were found to significantly affect the mortality rates at the end of the sixth week.

Table 4. Mortality rate (\%) and standard errors of the broiler chicks in the experimental groups

\begin{tabular}{|c|c|c|c|c|c|c|}
\hline \multirow{2}{*}{ Weeks } & \multicolumn{2}{|c|}{ Chick weight (g) } & \multirow{2}{*}{$\mathbf{P}$} & \multicolumn{2}{|c|}{ Toe length $(\mathrm{cm})$} & \multirow{2}{*}{$\mathbf{P}$} \\
\hline & Heavy $\geq 47.7$ & Light $<47.7$ & & Tall $\geq 2.01$ & Short $<2.01$ & \\
\hline 1 & $4.1 \pm 0.0 a$ & $4.1 \pm 0.03 a$ & NS & $0.0 \pm 0.0 a$ & $0.0 \pm 0.0 a$ & NS \\
\hline 2 & $0.0 \pm 0.0 a$ & $0.0 \pm 0.0 \mathrm{a}$ & NS & $0.0 \pm 0.0 a$ & $0.0 \pm 0.0 a$ & NS \\
\hline 3 & $0.0 \pm 0.0 a$ & $0.0 \pm 0.0 a$ & NS & $0.0 \pm 0.0 a$ & $0.0 \pm 0.0 a$ & NS \\
\hline 4 & $4.1 \pm 0.0 \mathrm{a}$ & $4.1 \pm 0.0 a$ & NS & $4.1 \pm 0.0 \mathrm{a}$ & $4.1 \pm 0.0 a$ & NS \\
\hline 5 & $8.3 \pm 0.15 a$ & $4.1 \pm 0.0 b$ & $*$ & $8.3 \pm 0.0 a$ & $4.1 \pm 0.0 b$ & $*$ \\
\hline 6 & $8.3 \pm 0.3 a$ & $8.3 \pm 0.3 a$ & NS & $4.1 \pm 0.0 \mathrm{a}$ & $4.1 \pm 0.0 a$ & NS \\
\hline $0-6$ & $4.1 \pm 1.3 \mathrm{a}$ & $3.4 \pm 1.2 b$ & $*$ & $2.7 \pm 1.6 \mathrm{a}$ & $2.0 \pm 1.2 \mathrm{~b}$ & $*$ \\
\hline \multirow{2}{*}{ Weeks } & \multicolumn{2}{|c|}{ Shank length $(\mathrm{cm})$} & D & \multicolumn{2}{|c|}{ Chick length $(\mathrm{cm})$} & D \\
\hline & Tall $\geq 2.9$ & Short $<2.9$ & $P$ & Tall $\geq 18.3$ & Short $<18.3$ & $r$ \\
\hline 1 & $0.0 \pm 0.0 a$ & $0.0 \pm 0.0 \mathrm{a}$ & NS & $0.0 \pm 0.0 b$ & $4.1 \pm 0.0 \mathrm{a}$ & $*$ \\
\hline 2 & $0.0 \pm 0.0 a$ & $0.0 \pm 0.0 a$ & NS & $0.0 \pm 0.0 a$ & $0.0 \pm 0.0 a$ & NS \\
\hline 3 & $0.0 \pm 0.0 a$ & $0.0 \pm 0.0 a$ & NS & $4.1 \pm 0.0 b$ & $8.3 \pm 0.0 a$ & $*$ \\
\hline 4 & $4.1 \pm 0.0 \mathrm{a}$ & $4.1 \pm 0.0 a$ & NS & $4.1 \pm 0.0 a$ & $4.1 \pm 0.0 \mathrm{a}$ & NS \\
\hline 5 & $4.1 \pm 0.0 a$ & $4.1 \pm 0.0 a$ & NS & $8.3 \pm 0.0 a$ & $4.1 \pm 0.0 b$ & $*$ \\
\hline 6 & $4.1 \pm 0.0 a$ & $4.1 \pm 0.0 a$ & NS & $4.1 \pm 0.0 a$ & $4.1 \pm 0.0 a$ & NS \\
\hline $0-6$ & $2.0 \pm 1.3 a$ & $2.0 \pm 1.2 \mathrm{a}$ & NS & $3.4 \pm 1.6 b$ & $4.1 \pm 1.3 a$ & $*$ \\
\hline
\end{tabular}

a, b: Differences between means in the same row with different letters are significant. NS: Non-significant, ${ }^{*}$ : $\mathrm{P}<0.05, * *: \mathrm{P}<0.01$.

\section{Conclusion}

Chick weight, toe length and chick length in daily chicks affected live weights of broilers at the end of fattening period. At the same period, shank length not affected live weights in broiler chickens. And also, considering traits such as feed consumption, feed efficiency and mortality, chick weight, toe length and chick length should be taken considerable as critical assessment of chick quality measurements as an indicator of broiler performance.

\section{References}

Abiola, S.S., Meshioye, O.O., Oyerinde, B.O., Bamgbose, M.A. 2008. Effect of egg size on hatchability of broiler chicks. Archivos de Zootecnia, 57: 83-86.

Geidam, Y.A., Ibrahim, U.I., Bukar, M.M., Gambo, H.I., Ojo, O. 2007. Quality Assessment of broiler day-old chicks supplied to Maiduguri, North-Eastern Nigeria. International Journal of Poultry Science, 6(2): 107-110. 
Hill, D. 2001. Chick length uniformity profiles as a field measurement of chick quality. Avian Poultry Biology Reviews, 12: 188 (Abst.).

Hill, D. 2002. Performance losses: Incubation and brooding. International Hatchery Practice, 16(8).

İpek, A., Sözcü, A. 2013. Broiler chick quality and scoring methods. U.Ü. Ziraat Fakültesi Dergisi, 27(2):131-137.

Kamanlı, S., Durmuş, İ., Demir, S. 2010. Hatching characteristics of abnormal eggs. Asian Journal of Animal and Veterinary Advances, 5(4): 271-274.

Kamanlı, S., Durmuş, i. 2014. Civciv kalitesi değerlendirme yöntemleri ve civciv kalitesinin iyileştirilmesi konusundaki son yaklaşımlar. Tavukçuluk Araştırma Dergisi, 11(1): 40-44.

Ketels, P. 2011. Controlling chick quality. Thesis Project. Livestock Management.

Meijerhof, R. 2005. What Count for Chick Quality? Hybro B.V., Boxmeer, the Netherlands.

Molenaar, R., Reijrink, I., Meijerhof, R., Brand, H.V.D., 2007. Relationship between chick length and chick weight at hatch and slaughter weight and breast meat yield in broilers. Proc. $3^{\text {rd }}$ Combined Workshop on Fundamental Physiology and Perinatal Development in Poultry, 5-10 October, Berlin.

Molenaar, R., Reijrink, I.A.M., Meijerhof, R., Brand, H.V.D., 2008. Relationship between hatchling length and weight on later productive performance in broilers. World's Poultry Science Journal, 64.

Ojepado, L.O. 2013. Evaluation of body weight and other linear parameters of Marshall Broiler for repeatability estimates. International Journal of Applied Agriculture and Apiculture Research, 9(1-2): 175-181.

Ould-Ali, D., Schulte-Drüggelte, R. 2016. Review of different day-old chick quality parameters in layer type breeds. International Poultry Production, 23: 4.

Petek, M., Orman, A., Dikmen, S., Alpay, F. 2008. Relations between day-old chick length and body weight in broiler, quail and layer. Uludağ Univ. J. Fac. Vet. Med., 27(1-2): 2528.

Reijrink, I., Molenaar, R. 2006. Chick Length \& Organ Development.

http://en.engormix.com/articles_view.aspx? AREA $=$ AVG\&id $=155 \&$ pag $=0$.

Şeremet, Ç. 2012. Civciv kalitesini etkileyen etmenler ve değerlendirme yöntemleri. Hayvansal Üretim 53(1): 38-43.
Tona, K., Onagbesan, O., De Ketelaere, B., Bruggeman, V., Decuypere, E. 2005. Interrelationships between chick quality parameters and the effect of individual parameter on broiler relative growth to 7 days of age. Arch. Geflügelkunde, 69(2): 6772.

Yahaya, H.K., Ibrahim, H., Abdulsalam, S. 2012. Correlation between body weight and body conformation of two broiler strains under the same dietary treatment. International Journal of Animal and Veterinary Advances, 4(3): 181-183.

Wilson, J.L., Weaver, Jr. W.D., Beane, W.L., Chreery, S.A. 1984. Effect of light and feeding space on leg abnormalities in broilers. Poultry Science, 63: 565-567.

Wolanski, N.J., Renema, R.A., Robinson, F.E., Carney, V.L., Fancher, B.I. 2006. Relationship between chick conformation and quality measures with early growth traits in males of eight selected pure or commercial broiler breeder strains. Poultry Science, 85(8): 1490-1497. 